\title{
Spatio-temporal changes in biomass carbon sinks in China's forests from 1977 to 2008
}

\author{
GUO ZhaoDi ${ }^{1}$, HU HuiFeng ${ }^{3}$, LI Pin ${ }^{1}$, LI NuYun ${ }^{4} \&$ FANG Jing Yun ${ }^{1,2^{*}}$ \\ ${ }^{1}$ College of Urban and Environmental Science, and Key Laboratory for Earth Surface Processes of Ministry of Education, Peking University, \\ Beijing 100871, China; \\ ${ }^{2}$ Climate Change Research Center, Academic Divisions of the Chinese Academy of Sciences at Peking University, Beijing 100871, China; \\ ${ }^{3}$ State Key Laboratory of Vegetation and Environmental Change, Institute of Botany, Chinese Academy of Sciences, Beijing 100093, China; \\ ${ }^{4}$ China Green Carbon Foundation, Beijing 100714, China
}

Received April 7, 2013; accepted April 14, 2013; published online May 29, 2013

\begin{abstract}
Forests play a leading role in regional and global carbon $(\mathrm{C})$ cycles. Detailed assessment of the temporal and spatial changes in $\mathrm{C}$ sinks/sources of China's forests is critical to the estimation of the national $\mathrm{C}$ budget and can help to constitute sustainable forest management policies for climate change. In this study, we explored the spatio-temporal changes in forest biomass $\mathrm{C}$ stocks in China between 1977 and 2008, using six periods of the national forest inventory data. According to the definition of the forest inventory, China's forest was categorized into three groups: forest stand, economic forest, and bamboo forest. We estimated forest biomass $\mathrm{C}$ stocks for each inventory period by using continuous biomass expansion factor (BEF) method for forest stands, and the mean biomass density method for economic and bamboo forests. As a result, China's forests have accumulated biomass $\mathrm{C}$ (i.e., biomass $\mathrm{C}$ sink) of $1896 \mathrm{Tg}\left(1 \mathrm{Tg}=10^{12} \mathrm{~g}\right)$ during the study period, with 1710,108 and $78 \mathrm{Tg} \mathrm{C}$ in forest stands, and economic and bamboo forests, respectively. Annual forest biomass $\mathrm{C}$ sink was $70.2 \mathrm{Tg} \mathrm{C} \mathrm{a}{ }^{-1}$, offsetting $7.8 \%$ of the contemporary fossil $\mathrm{CO}_{2}$ emissions in the country. The results also showed that planted forests have functioned as a persistent $\mathrm{C}$ sink, sequestrating $818 \mathrm{Tg} \mathrm{C}$ and accounting for $47.8 \%$ of total $\mathrm{C}$ sink in forest stands, and that the old-, mid- and young-aged forests have sequestrated 930, 391 and $388 \mathrm{Tg} \mathrm{C}$ from 1977 to 2008 . Our results suggest that China's forests have a big potential as biomass $\mathrm{C}$ sink in the future because of its large area of planted forests with young-aged growth and low $\mathrm{C}$ density.
\end{abstract}

bamboo forests, biomass carbon stock, carbon sink, forest inventory, economic forests, natural forests, planted forests

Citation: Guo Z D, Hu H F, Li P, et al. Spatio-temporal changes in biomass carbon sinks in China's forests from 1977 to 2008. Sci China Life Sci, 2013, 56: 661-671, doi: 10.1007/s11427-013-4492-2

Forests play a dominant role in regional and global carbon (C) cycles because they contain $85 \%-90 \%$ of total terrestrial vegetation biomass and annually exchange up to $90 \%$ of total terrestrial ecosystem $\mathrm{C}$ with the atmosphere through photosynthesis and respiration [1-12]. Forests become sources of atmospheric $\mathrm{CO}_{2}$ when disturbed by human and natural disturbances, but they can also function as $\mathrm{C}$ sinks to

*Corresponding author (email: jyfang@urban.pku.edu.cn) sequester or conserve significant quantities of $\mathrm{C}$ during regrowth after disturbance [11,13-16]. Because of their importance in the $\mathrm{C}$ cycles, the Kyoto Protocol clearly suggested increasing $\mathrm{C}$ sequestration through afforestation and reforestation to meet greenhouse gas emission targets during commitment periods for signatory countries of the United Nations Framework Convention on Climate Change (UNFCCC) [14].

Estimating broad-scale biomass $\mathrm{C}$ stocks and their dy- 
namics has been one of the important issues in the study of the global $\mathrm{C}$ cycle. In recent decades, forest inventory data have been widely used to estimate $\mathrm{C}$ stocks and fluxes for the world's forests at a regional or national scale, because these data are generally collected across the whole area of the forests and designed to be statistically valid $[3,5,7,15,17,18]$. For example, based on U.S. Forest Inventory and Analysis (FIA) data, Brown and Schroeder [15] estimated that eastern U.S. forests annually accumulated $\sim 174 \mathrm{Tg} \mathrm{C}\left(1 \mathrm{Tg}=10^{12} \mathrm{~g}\right)$ during the late 1980 s and early 1990s and offset about $13 \%$ of the $\mathrm{C}$ emissions from fossil fuels and cement manufacturing in the United States during the early 1990s [19]. Similarly, Europe's terrestrial ecosystems have absorbed $7 \%-12 \%$ of European anthropogenic $\mathrm{CO}_{2}$ emissions [7].

Located in the eastern margin of Eurasia, China ranks the fifth in its forest area in the world [20] and encompasses various forest biomes, from boreal forests in the north to the subtropical/tropical evergreen broadleaf forests in the south [21], which provides a unique area to study the regional forest $\mathrm{C}$ cycle. In addition, with the implementation of national afforestation and reforestation programs since the late 1970s, such as the Three-north Protective Forest Program, the Natural Forest Conservation Program, and the Wetland Restoration Program, forest ecosystems in China are thought to have significantly contributed to the regional and global C sinks in the past several decades [3,11,18,22-32]. Based on national forest inventory data, Fang et al. [3] estimated changes in the national $\mathrm{C}$ stocks of living forest biomass between 1949 and 1998, concluding that China's forests had functioned as a $\mathrm{C}$ sink at a mean annual accumulation rate of $0.021 \mathrm{Pg} \mathrm{C}\left(1 \mathrm{Pg}=10^{15} \mathrm{~g}\right)$ during the study period, mainly due to forest expansion and regrowth. One decade later, Pan et al. [11] updated these inventory data and found that the magnitude of China's forest biomass $\mathrm{C}$ sink almost doubled from $0.060 \mathrm{Pg} \mathrm{C}^{-1}$ in the 1990s (1990-1999) to $0.115 \mathrm{Pg} \mathrm{C} \mathrm{a}^{-1}$ in the 2000s (2000-2007). While these studies have contributed to understanding of the role of China's forests in the regional and global $\mathrm{C}$ budget, they lack systematic and detailed analysis on changes in forest biomass $\mathrm{C}$ stocks with different zonal forest type, age class, and different province. Therefore, based on the up-todate national forest inventory data since the late 1970s, this study is to explore: (i) the temporal changes in biomass $\mathrm{C}$ stocks for China's forests and among forest stands, economic and bamboo forests, and (ii) the changes in biomass $\mathrm{C}$ stocks in the forest stands, and planted and natural forests, with forest type and age class.

\section{Data and methods}

China's forest inventory data for the period of 1977-1981, 1984-1988, 1989-1993, 1994-1998, 1999-2003, and
2004-2008 were used in this study. According to the definition of China's forest resource inventory, China's forest was categorized into three groups: forest stand (including planted and natural forests), economic forest (woods with the production of fruits, edible oils, drinks, flavorings, industrial raw materials, and medicinal materials as the main purposes), and bamboo forest. However, the forest inventory provides different information for these different forest groups: it documents the areas and timber volumes by dominant tree species and by age class in each province for forest stands, as well as the respective areas and volumes of natural forests and plantations for each province, and only the forest area in each province for economic and bamboo forests. Note that due to the lack of data, forest in Hong Kong, Macao and Taiwan was not included in this study.

Three methods, including the mean biomass density method, the mean biomass expansion factor (BEF, ratio of forest biomass to timber volume) method, and the continuous BEF method (the function of BEF as timber volume), are commonly used to estimate forest biomass $\mathrm{C}$ stocks across the world $[33,34]$. Using China's forest inventory data between 1984 and 2003, Guo et al. [34] compared these three methods and concluded that the continuous BEF method was most reasonable and accurate to estimate regional forest biomass when there are sufficient forest inventory data, as well as field measurement data. Therefore, we estimated forest biomass $\mathrm{C}$ stocks for each inventory period by using the continuous BEF method for forest stands, and the mean biomass density method for economic and bamboo forests. It should be noted that a ratio of 0.5 was used in this study to convert biomass to $\mathrm{C}$ stock.

\subsection{Forest stands}

Because forest inventory data only document information on area and timber volume of forest stands, it is necessary to develop allometric relationships between forest biomass and forest timber volume to obtain $\mathrm{BEF}$ for each forest type $[17,23,33]$. Previous studies have suggested that the value of BEF varies with forest age, site class, stand density and quality $[3,17]$. Fang and his colleagues $[3,14,15,17,23,35,36]$ have derived a simple reciprocal equation from direct field measurements to express the BEF-timber volume relationship for a specific forest type (eq. (1), Table S1 in Supporting Information), and one can easily scale up to calculate regional forest biomass based on direct field measurements and forest inventory data by using these equations [37]. For details about this method, see Fang et al. [3,18] and Guo et al. [34].

$$
\mathrm{BEF}=\mathrm{a}+\mathrm{b} / x
$$

where $x$ is the timber volume per unit area, $\mathrm{a}$ and $\mathrm{b}$ are constants for a specific forest type, and BEF is the biomass expansion factor.

It should be noted that since 1994, the definition of forest 
stands in China's forest resource inventory has been changed from $>30 \%$ canopy coverage to $\geqslant 20 \%$ canopy coverage. In order to make our results comparable among different periods, Fang et al. [18] analyzed the 1994-1998 inventory data which provided both criteria (20\% and $30 \%$ canopy coverage), and found the robust linear relationships between the two criteria for the forest area and biomass $\mathrm{C}$ stocks at the provincial level. In this study, we modified their equations with power function relationships (eqs. (2) and (3)) to obtain better estimates.

$$
\begin{aligned}
\text { AREA }_{0.2} & =1.290 \times \text { AREA }_{0.3}^{0.995}\left(R^{2}=0.996, n=30\right), \\
\text { CARBON }_{0.2} & =1.147 \times \mathrm{CARBON}_{0.3}{ }^{0.996}\left(R^{2}=0.999, n=30\right),
\end{aligned}
$$

where AREA and CARBON are the forest stand area $\left(10^{4}\right.$ ha) and biomass $\mathrm{C}$ stock ( $\mathrm{Tg} \mathrm{C}$ ) in a province, respectively; subscripts 0.3 and 0.2 represent the criterion of $>30 \%$ and $\geqslant 20 \%$ canopy coverage, respectively.

In addition, because early forest inventory data only documented total area and volume of natural and planted forests for each province without detailed information on dominant tree species for each type, we could not use the continuous BEF method as the whole forest stands to calculate biomass $\mathrm{C}$ stocks in each inventory period for natural and planted forests. Therefore, following Fang and Chen [38], we established a robust linear relationship between the mean biomass density and mean volume density at the provincial level (eq. (4), Figure 1). Using this equation, we first calculated separately the biomass $\mathrm{C}$ stocks of natural and planted forests for each province and each inventory period, and then obtained their corresponding proportions in each province and each inventory period. The final biomass $\mathrm{C}$ stocks of natural and planted forests were derived by multiplying these corresponding proportions to total biomass $\mathrm{C}$ stock of forest stands, which was obtained using the continuous BEF method.

$$
B D=0.704 \times V D+19.953\left(R^{2}=0.968, n=211\right),
$$

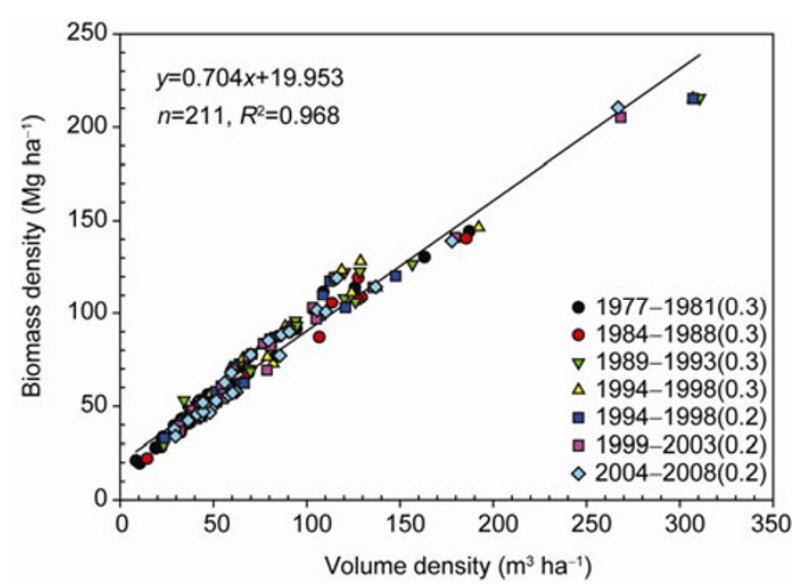

Figure 1 Relationship between the mean biomass density $\left(\mathrm{Mg} \mathrm{ha}^{-1}\right)$ and the mean volume density $\left(\mathrm{m}^{3} \mathrm{ha}^{-1}\right)$ at provincial level $(0.3$ and 0.2 in parenthesis show the criterion of $>30 \%$ canopy coverage and $\geqslant 20 \%$ canopy coverage, respectively). where $B D$ and $V D$ are the mean biomass density $\left(\mathrm{Mg} \mathrm{ha}^{-1}\right.$, $\left.1 \mathrm{Mg}=10^{6} \mathrm{~g}\right)$ and mean volume density $\left(\mathrm{m}^{3} \mathrm{ha}^{-1}\right)$ of forest stands in each province in different period, respectively.

\subsection{Economic and bamboo forests}

Because forest inventory only documents the area of economic forests in each province, we estimated biomass $\mathrm{C}$ stocks in China's economic forests between 1977 and 2008 by multiplying the mean biomass density $\left(23.7 \mathrm{Mg} \mathrm{ha}^{-1}\right.$, Fang et al. [22]) with the area of economic forests in each province in each inventory period.

Forest inventory documents the areas of moso bamboo and other bamboo forests in each province. We established a literature-reviewed database of bamboo biomass, which contained 37 sets of biomass data for moso bamboo forests and 43 sets for other bamboo forests. The mean biomass density of moso bamboo and other bamboo forests was estimated as 81.9 and 53.1 $\mathrm{Mg} \mathrm{ha}^{-1}$ respectively, based on the database. We therefore can obtain biomass $\mathrm{C}$ stocks in China's bamboo forests in the different inventory periods, using the mean biomass density for each bamboo type and areas in each province.

\section{Results}

\subsection{Biomass C stocks and C sinks of China's forests}

Total forest biomass $\mathrm{C}$ stock increased by $38.6 \%$ from $4972 \mathrm{Tg}$ C (i.e., $4.972 \mathrm{Pg} \mathrm{C}$ ) in the early 1980s (1977-1981) to $6868 \mathrm{Tg} \mathrm{C}$ in the late 2000s (2004-2008), with a net accumulation of $1914 \mathrm{Tg} \mathrm{C}$ and an overall biomass $\mathrm{C}$ sink rate of $70.2 \mathrm{Tg} \mathrm{C} \mathrm{a}^{-1}$ (Table 1). As shown in Table 1, biomass $\mathrm{C}$ sinks varied greatly in different periods: the $\mathrm{C}$ sink in 1994-1998 was $10.1 \mathrm{Tg} \mathrm{C} \mathrm{a}^{-1}$, and then dramatically increased to $114.9 \mathrm{Tg} \mathrm{C} \mathrm{a}^{-1}$ in 2004-2008, implying a significant increase in $\mathrm{C}$ sink in China's forests.

Occupying $84.4 \%-89.4 \%$ of total forest area, forest stands have stored $93.2 \%-94.9 \%$ of total biomass $\mathrm{C}$ stock and net accumulated $\mathrm{C}$ of $1710 \mathrm{Tg}$, at an average rate of 63.3 $\mathrm{Tg} \mathrm{C} \mathrm{a}{ }^{-1}$, which accounted for $90.2 \%$ of total biomass C sink between 1977 and 2008. Net C gain was found between two sequential inventory periods, except a slight decrease of $8 \mathrm{Tg} \mathrm{C}$ in 1994-1998 probably due to the statistical error on the forest area, and the maximum biomass $\mathrm{C}$ sink was found in 2004-2008 with the value of $112.9 \mathrm{Tg} \mathrm{C}$ $\mathrm{a}^{-1}$. The area-weighted mean biomass $\mathrm{C}$ density also increased from initial 38.2 $\mathrm{Mg} \mathrm{C} \mathrm{ha}^{-1}$ to $41.3 \mathrm{Mg} \mathrm{C} \mathrm{ha}^{-1}$ in the late 2000s (2004-2008).

Over the past three decades, economic and bamboo forests have occupied $8.2 \%-12.9 \%$ and $2.3 \%-3.0 \%$ of total forest area, and stored $2.7 \%-4.1 \%$ and $2.4 \%-2.9 \%$ of total biomass C stock, respectively. During the period of 1977-2008, economic and bamboo forests have separately 
Table 1 The magnitude and change of C stocks and C sinks in China's forests during 1977-2008

\begin{tabular}{|c|c|c|c|c|c|c|c|c|c|c|c|c|c|}
\hline \multirow[b]{2}{*}{ Period } & \multicolumn{3}{|c|}{ All forests } & \multicolumn{4}{|c|}{ Forest stands } & \multicolumn{3}{|c|}{ Economic forests } & \multicolumn{3}{|c|}{ Bamboo forests } \\
\hline & $\begin{array}{c}\text { Area } \\
\left(10^{4} \text { ha }\right)\end{array}$ & $\begin{array}{l}\text { C stock } \\
(\mathrm{Tg} \mathrm{C}) \\
\end{array}$ & $\begin{array}{c}\mathrm{C} \text { sink } \\
\left(\mathrm{Tg} \mathrm{C} \mathrm{a}^{-1}\right) \\
\end{array}$ & $\begin{array}{c}\text { Area } \\
\left(10^{4} \text { ha }\right)\end{array}$ & $\begin{array}{l}\text { C stock } \\
(\mathrm{Tg} \mathrm{C}) \\
\end{array}$ & $\begin{array}{c}\text { C density } \\
\left(\mathrm{Mg} \mathrm{C} \mathrm{ha}^{-1}\right)\end{array}$ & $\begin{array}{c}\mathrm{C} \text { sink } \\
\left(\mathrm{Tg} \mathrm{C} \mathrm{a}^{-1}\right) \\
\end{array}$ & $\begin{array}{c}\text { Area } \\
\left(10^{4} \text { ha }\right)\end{array}$ & $\begin{array}{l}\text { C stock } \\
(\mathrm{Tg} \mathrm{C}) \\
\end{array}$ & $\begin{array}{c}\mathrm{C} \text { sink } \\
\left(\mathrm{Tg} \mathrm{C} \mathrm{a}^{-1}\right) \\
\end{array}$ & $\begin{array}{c}\text { Area } \\
\left(10^{4} \text { ha }\right) \\
\end{array}$ & $\begin{array}{l}\text { C stock } \\
(\mathrm{Tg} \mathrm{C}) \\
\end{array}$ & $\begin{array}{c}\mathrm{C} \text { sink } \\
\left(\mathrm{Tg} \mathrm{C} \mathrm{a}^{-1}\right) \\
\end{array}$ \\
\hline $1977-1981$ & 13798 & 4972 & - & 12350 & 4717 & 38.2 & - & 1128 & 134 & - & 320 & 121 & - \\
\hline 1984-1988 & 14898 & 5178 & 29.5 & 13169 & 4885 & 37.1 & 23.9 & 1374 & 163 & 4.2 & 355 & 131 & 1.4 \\
\hline 1989-1993 & 15960 & 5731 & 110.6 & 13971 & 5402 & 38.7 & 103.5 & 1610 & 191 & 5.6 & 379 & 138 & 1.5 \\
\hline 1999-2003 & 16902 & 6293 & 102.3 & 14279 & 5862 & 41.1 & 94.9 & 2139 & 253 & 2.8 & 484 & 177 & 4.7 \\
\hline 2004-2008 & 18138 & 6868 & 114.9 & 15559 & 6427 & 41.3 & 112.9 & 2041 & 242 & -2.3 & 538 & 199 & 4.3 \\
\hline 1977-2008 & & & 70.2 & & & & 63.3 & & & 4.0 & & & 2.9 \\
\hline
\end{tabular}

accumulated 108 and $78 \mathrm{Tg} \mathrm{C}$, which equaled $5.7 \%$ and $4.1 \%$ of total biomass $\mathrm{C}$ sink in China's forests. Annual biomass $\mathrm{C}$ sink rate averaged $4.0 \mathrm{Tg} \mathrm{C} \mathrm{a}^{-1}$ for economic forests, ranging from $-2.3 \mathrm{Tg} \mathrm{C} \mathrm{a}^{-1}$ in $2004-2008$ to $9.8 \mathrm{Tg}$ $\mathrm{C} \mathrm{a}^{-1}$ in 1994-1998, and 2.9 $\mathrm{Tg} \mathrm{C} \mathrm{a}^{-1}$ for bamboo forests, ranging from $1.4 \mathrm{Tg} \mathrm{C} \mathrm{a}^{-1}$ in $1977-1981$ to $4.7 \mathrm{Tg} \mathrm{C} \mathrm{a}^{-1}$ in 1999-2003, respectively.

\subsection{Spatio-temporal distribution of biomass $\mathrm{C}$ sink of forest stands}

Figure 2 presents provincial biomass $\mathrm{C}$ stock, density, and C sink in China's forest stands between the early 1980s (1977-1981) and the late 2000s (2004-2008), together with the forest area. In 1977-1981, the largest biomass C stock (801.8 Tg C) was in Heilongjiang, accounting for $17.0 \%$ of total biomass $\mathrm{C}$ stock in China's forest stands, followed by Tibet (621.9 Tg C, 13.2\%), Yunnan (556.6 Tg C, 11.8\%), Inner Mongolia (510.7 Tg C, 10.8\%), and Sichuan (469.6 $\mathrm{Tg} \mathrm{C}, 10.0 \%$ ). The area-weighted biomass $\mathrm{C}$ density ranged from 8.8 (Shanghai) to $78.8 \mathrm{Mg} \mathrm{C} \mathrm{ha}^{-1}$ (Tibet), with an overall mean of $38.2 \mathrm{Mg} \mathrm{C}^{-1}$ across the country's forest stands. Thirty years later, the largest biomass C stock (884.7 $\mathrm{Tg} \mathrm{C)}$ was switched to Tibet, which accounted for $13.8 \%$ of total forest stand biomass $\mathrm{C}$ stock. Next to Tibet, it was Heilongjiang (815.5 Tg C, 12.7\%), Yunnan (747.8 Tg C, $11.6 \%)$, Sichuan (719.4 Tg C, 11.2\%), and Inner Mongolia (652.8 Tg C, 10.2\%). In 2004-2008, the area-weighted biomass $\mathrm{C}$ density ranged from $16.9 \mathrm{Mg} \mathrm{C} \mathrm{ha}^{-1}$ (Shanghai) to 105.2 $\mathrm{Mg} \mathrm{C} \mathrm{ha}^{-1}$ (Tibet), with an overall mean of $41.3 \mathrm{Mg}$ $\mathrm{C} \mathrm{ha}^{-1}$.

As shown in Figure 2, forest stands in all provinces have functioned as C sinks during 1977-2008, and the largest $\mathrm{C}$ sink was in Tibet (280.8 Tg C), accounting for $15.4 \%$ of total biomass $\mathrm{C}$ sink in China's forest stands, followed by Sichuan (249.7 Tg C, 14.6\%), Yunnan (191.2 Tg C, 11.2\%), and Inner Mongolia (142.1 Tg C, 8.3\%). In addition, the area of forest stands had increased in all provinces, except slight decreases in Jilin by $26.6 \times 10^{4}$ ha and in Gansu by $4.7 \times 10^{4}$ ha.

\subsection{Biomass C stocks in planted and natural forests}

The biomass $\mathrm{C}$ stocks and $\mathrm{C}$ sinks in planted and natural forests are given in Table 2 . The area of planted forests had increased by $24.05 \times 10^{6}$ ha since the early 1980 s (19771981), which accounted for $74.9 \%$ of total area increment in the area of the forest stands, or $55.4 \%$ of China's forests, mainly due to afforestation and reforestation practices in the country in recent decades. Biomass $\mathrm{C}$ stock of planted forests had increased $>3$ times from $250 \mathrm{Tg} \mathrm{C}$ in the early 1980s (1977-1981) to $1063 \mathrm{Tg} \mathrm{C}$ in the late 2000s (2004-2008) and the proportion of biomass C stock in planted forests had consistently increased from initial 5.3\% to $16.8 \%$ in 2004-2008. Consequently, planted forests had continuously sequestrated $\mathrm{C}$ of $818 \mathrm{Tg}$ from 1977 through 2008 , at an average rate of $30.3 \mathrm{Tg} \mathrm{C} \mathrm{a}^{-1}$, which accounted for $47.8 \%$ of total biomass $\mathrm{C}$ sink in China's forest stands or $43.1 \%$ in China's forests. Compared with the planted forests, natural forests did not show a persistent $\mathrm{C}$ gain: it had released $132 \mathrm{Tg} \mathrm{C}$ and sequestrated $1024 \mathrm{Tg} \mathrm{C}$ during the study period, with a net accumulation of $892 \mathrm{Tg} \mathrm{C}$ and at an average rate of $33.0 \mathrm{Tg} \mathrm{C} \mathrm{a}{ }^{-1}$. It should be noted that since the late 1990s (1994-1998), natural forests have functioned as a persistent $\mathrm{C}$ sink, probably due to the implement of nation-wide Natural Forest Conservation Program starting in 1998.

Further, as shown in Table 2, the area-weighted mean biomass density of planted forests increased dramatically, from $15.6 \mathrm{Mg} \mathrm{C}^{-1}$ in the early 1980s (1977-1981) to $26.7 \mathrm{Mg} \mathrm{C} \mathrm{ha}{ }^{-1}$ in the late 2000s (2004-2008), which equaled to $37.7 \%-57.5 \%$ of that of natural forests, indicating that planted forests could still sequestrate more $\mathrm{C}$ by their regrowth in the future.

There was considerable spatial (or regional) difference in biomass $\mathrm{C}$ sinks in planted and natural forests over the past 30 years (Figure 3 ). Planted forests had acted as $\mathrm{C}$ sinks in all provinces during the period of 1977-2008 and the largest sink (81.1 Tg C) was in Sichuan, followed by Fujian (68.9 Tg C), Heilongjiang (60.9 Tg C), and Hunan (58.6 Tg C). For the natural forests, 25 of 30 provinces in China were C sinks and Tibet (262.1 Tg C), Sichuan (168.6 Tg C), 


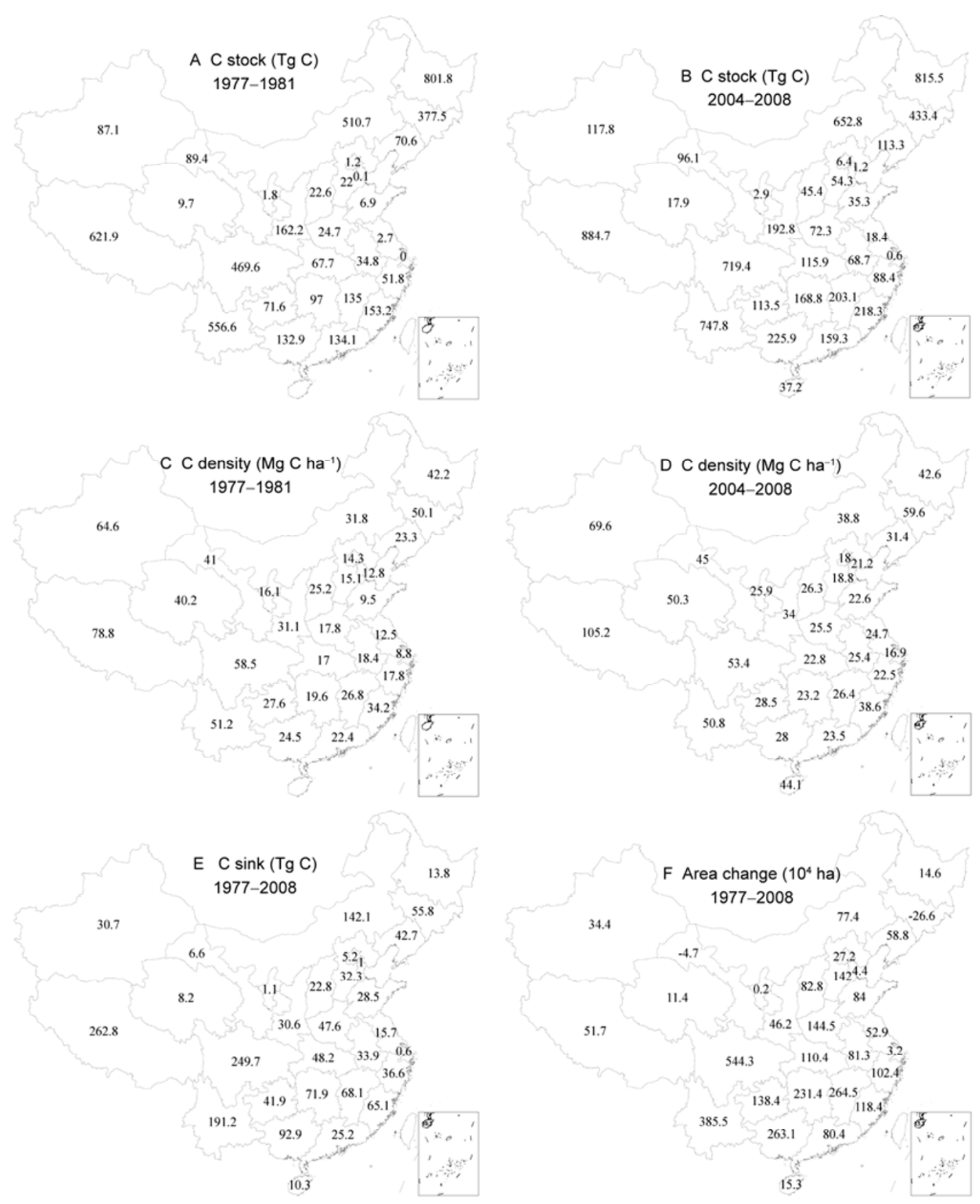

Figure 2 Spatio-temporal distributions in biomass C stocks, C densities, C sinks, and area change in forest stands during 1977-2008. A, C stock in 1977-1981. B, C stock in 2004-2008. C, C density in 1977-1981. D, C density in 2004-2008. E, C sink during 1977-2008. F, Area change during 1977-2008. There are no data in Hainan in 1977-1981, so the results of C sink and area change in Hainan are the values during 1984-2008.

Table 2 Area, C stock, C density, and C sink for planted and natural forests in China during 1977-2008

\begin{tabular}{|c|c|c|c|c|c|c|c|c|}
\hline \multirow[b]{2}{*}{ Period } & \multicolumn{4}{|c|}{ Planted forests } & \multicolumn{4}{|c|}{ Natural forests } \\
\hline & $\begin{array}{c}\text { Area } \\
\left(10^{4} \mathrm{ha}\right)\end{array}$ & $\begin{array}{l}\text { C stock } \\
(\mathrm{Tg} \mathrm{C})\end{array}$ & $\begin{array}{c}\text { C density } \\
\left(\mathrm{Mg} \mathrm{C} \mathrm{ha-1)}^{-1}\right)\end{array}$ & $\begin{array}{c}\mathrm{C} \text { sink } \\
\left(\mathrm{Tg} \mathrm{C} \mathrm{a}^{-1}\right)\end{array}$ & $\begin{array}{c}\text { Area } \\
\left(10^{4} \mathrm{ha}\right)\end{array}$ & $\begin{array}{l}\text { C stock } \\
(\mathrm{Tg} \mathrm{C})\end{array}$ & $\begin{array}{c}\mathrm{C} \text { density } \\
\left(\mathrm{Mg} \mathrm{C} \mathrm{ha-}^{-1}\right)\end{array}$ & $\begin{array}{c}\mathrm{C} \text { sink } \\
\left(\mathrm{Tg} \mathrm{C} \mathrm{a}^{-1}\right)\end{array}$ \\
\hline 1977-1981 & 1595 & 250 & 15.6 & - & 10755 & 4468 & 41.5 & - \\
\hline 1984-1988 & 2347 & 418 & 17.8 & 24.1 & 10822 & 4467 & 41.3 & -0.1 \\
\hline 1989-1993 & 2675 & 526 & 19.7 & 21.6 & 11296 & 4876 & 43.2 & 81.9 \\
\hline 1994-1998 & 2914 & 642 & 22.0 & 23.3 & 10326 & 4746 & 46.0 & -26.2 \\
\hline 1999-2003 & 3229 & 836 & 25.9 & 38.7 & 11049 & 5026 & 45.5 & 56.2 \\
\hline 2004-2008 & 4000 & 1067 & 26.7 & 46.2 & 11559 & 5360 & 46.4 & 66.7 \\
\hline $1977-2008$ & & & & 30.3 & & & & 33.0 \\
\hline
\end{tabular}




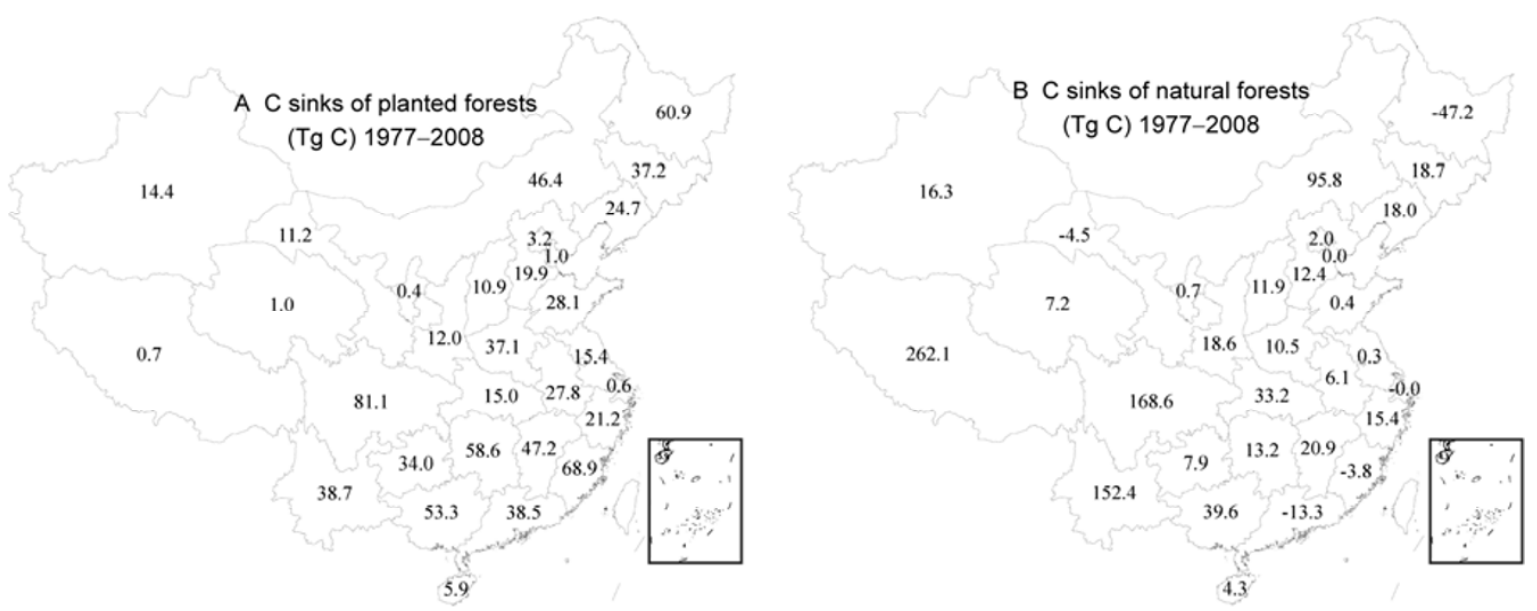

Figure 3 The regional distribution of biomass $\mathrm{C}$ sinks $\left(\mathrm{Tg} \mathrm{C} \mathrm{a}^{-1}\right)$ of planted and natural forest stands in each province during 1977-2008. A, C sinks of planted forests. B, C sinks of natural forests.

Yunnan (152.4 Tg C), and Inner Mongolia (95.8 Tg C) had the highest $\mathrm{C}$ sinks, which together accounted for $76.1 \%$ of total biomass $\mathrm{C}$ sink in natural forests across the country. The rest five provinces had released $\mathrm{C}$ and the largest biomass $\mathrm{C}$ source was in Heilongjiang $(-47.2 \mathrm{Tg} \mathrm{C})$, followed by Guangdong (-13.3 Tg C), Gansu (-4.5 Tg C), Fujian $(-3.8 \mathrm{Tg} \mathrm{C})$, and Shanghai $(-0.02 \mathrm{Tg} \mathrm{C})$.

\subsection{Biomass C stocks of forest stands by forest type}

China has almost all major forest types of Northern Hemisphere, with tropical rainforests in the south and boreal forests in the north [39]. To document the biomass $\mathrm{C}$ sink in various zonal forest types, we grouped China's forest stands into five zonal forest types based on dominant tree species according to Fang [40]: boreal forests, temperate coniferous forests, temperate deciduous forests, warm-temperate/subtropical mixed forests, and evergreen broadleaf forests (Table 3).

Table 3 depicts temporal change in biomass $\mathrm{C}$ stocks and C sinks during the period of 1977-2008 by zonal forest type. In the early 1980s (1977-1981), the largest biomass C stock (1449 $\mathrm{Tg} \mathrm{C})$ was in boreal forests, which accounted for $31.0 \%$ of total country biomass $\mathrm{C}$ stock of forest stands. The biomass C stocks of evergreen broadleaf forests (1282 Tg C), temperate deciduous forests $(870 \mathrm{Tg} \mathrm{C})$, temperate/ subtropical mixed forests ( $816 \mathrm{Tg} \mathrm{C}$ ), and temperate coniferous forests $(282 \mathrm{Tg} \mathrm{C})$ accounted for $27.2 \%, 18.5 \%$, $17.3 \%$, and $6.0 \%$ of China's forest stand biomass $\mathrm{C}$ stock, respectively. However, this order has been changed 30 years: evergreen broadleaf forests stored the largest biomass $\mathrm{C}$ of $1901 \mathrm{Tg} \mathrm{C}(29.6 \%)$, followed by temperate deciduous forests (1577 Tg C, 24.5\%), boreal forests (1242 Tg C, 19.3\%), temperate/subtropical mixed forests (1156 Tg C, 18.0\%), and temperate coniferous forests (552 $\mathrm{Tg} \mathrm{C}, 8.6 \%)$. Consequently, four of five zonal forest types had functioned as $\mathrm{C}$ sinks during the period of 1977-2008 and the net C accu- mulation was $706 \mathrm{Tg} \mathrm{C}\left(26.2 \mathrm{Tg} \mathrm{C} \mathrm{a}^{-1}\right)$ in temperate deciduous forests, $617 \mathrm{Tg} \mathrm{C}\left(22.8 \mathrm{Tg} \mathrm{C} \mathrm{a}^{-1}\right)$ in evergreen broadleaf forests, $340 \mathrm{Tg} \mathrm{C}\left(12.6 \mathrm{Tg} \mathrm{C} \mathrm{a}^{-1}\right)$ in temperate/subtropical mixed forests, and $268 \mathrm{Tg} \mathrm{C}\left(9.9 \mathrm{Tg} \mathrm{C} \mathrm{a}^{-1}\right)$ in temperate coniferous forests. Boreal forests have functioned as a stable $\mathrm{C}$ sink by sequestrating $220 \mathrm{Tg} \mathrm{C}$ between 1977 and 1993, while switched to a C source by releasing $441 \mathrm{Tg}$ C from 1994 through 2008, with a net release of 221 $\mathrm{Tg} \mathrm{C}$ over the past 30 years. These differences in biomass $\mathrm{C}$ sinks in these five zonal forest types were largely attributed to the change in forest area. Over the past three decades, forest area has increased by $14.11 \times 10^{6}$ ha in temperate deciduous forests, $13.09 \times 10^{6}$ ha in evergreen broadleaf forests, $7.41 \times 10^{6}$ ha in temperate coniferous forests, and $1.8 \times 10^{6}$ ha in temperate/subtropical mixed forests, but decreased by $3.69 \times 10^{6}$ ha in boreal forests.

As shown in Table 3, during the period of 1977-2008, the area-weighted mean biomass $\mathrm{C}$ density has increased by $35.7 \%$ (7.9 $\mathrm{Mg} \mathrm{C} \mathrm{ha}^{-1}$ ) in temperate/subtropical mixed forests, $15.0 \%\left(5.4 \mathrm{Mg} \mathrm{C} \mathrm{ha}^{-1}\right)$ in temperate deciduous forests, $5.8 \%\left(2.3 \mathrm{Mg} \mathrm{C} \mathrm{ha}^{-1}\right)$ in evergreen broadleaf forests, $3.5 \%$ $\left(1.2 \mathrm{Mg} \mathrm{C} \mathrm{ha}^{-1}\right)$ in temperate coniferous forests, and $2.2 \%$ $\left(1.5 \mathrm{Mg} \mathrm{C} \mathrm{ha}{ }^{-1}\right)$ in boreal forests. By the late 2000s (2004-2008), boreal forests contained the highest biomass $\mathrm{C}$ density of $68.8 \mathrm{Mg} \mathrm{C} \mathrm{ha}^{-1}$, due to the higher biomass $\mathrm{C}$ densities of dominant tree species (125.1 Mg C ha ${ }^{-1}$ for Abies, 88.6 $\mathrm{Mg} \mathrm{C} \mathrm{ha}{ }^{-1}$ for Picea, and 44.3 $\mathrm{Mg} \mathrm{C} \mathrm{ha}^{-1}$ for Larix in 2004-2008). Next to this, it was $42.2 \mathrm{Mg} \mathrm{C} \mathrm{ha}^{-1}$ in evergreen broadleaf forests, $41.3 \mathrm{Mg} \mathrm{C} \mathrm{ha}{ }^{-1}$ in temperate deciduous forests, $35.1 \mathrm{Mg} \mathrm{C} \mathrm{ha}^{-1}$ in temperate coniferous forests, and $30.0 \mathrm{Mg} \mathrm{C} \mathrm{ha}^{-1}$ in temperate/subtropical mixed forests.

\subsection{Biomass $\mathrm{C}$ stocks of forest stands by forest age class}

According to forest inventory data, China's forest stands 
Table 3 The magnitude and change of biomass C stocks in different zonal forest types in China during 1977-2008

\begin{tabular}{|c|c|c|c|c|c|}
\hline Zonal forest group ${ }^{\text {a) }}$ & Period & $\begin{array}{c}\text { Area } \\
\left(10^{4} \text { ha }\right)\end{array}$ & $\begin{array}{l}\text { C stock } \\
(\mathrm{Tg} \mathrm{C})\end{array}$ & $\begin{array}{c}\text { C density } \\
\left(\mathrm{Mg} \mathrm{C} \mathrm{ha}^{-1}\right)\end{array}$ & $\begin{array}{c}\mathrm{C} \text { sink } \\
\left(\mathrm{Tg} \mathrm{C} \mathrm{a}^{-1}\right) \\
\end{array}$ \\
\hline \multirow{7}{*}{ Boreal forests $^{\mathrm{b})}$} & $1977-1981$ & 2174 & 1463 & 67.3 & - \\
\hline & 1984-1988 & 2196 & 1481 & 67.4 & 2.6 \\
\hline & 1989-1993 & 2350 & 1683 & 71.6 & 40.4 \\
\hline & 1994-1998 & 2131 & 1637 & 76.8 & -9.3 \\
\hline & 1999-2003 & 1826 & 1263 & 69.2 & -74.7 \\
\hline & 2004-2008 & 1805 & 1242 & 68.8 & -4.3 \\
\hline & 1977-2008 & & & & -8.2 \\
\hline \multirow{7}{*}{ Temperate coniferous forests ${ }^{\mathrm{c})}$} & 1977-1981 & 837 & 284 & 33.9 & - \\
\hline & 1984-1988 & 1055 & 319 & 30.3 & 5.0 \\
\hline & 1989-1993 & 1114 & 386 & 34.6 & 13.3 \\
\hline & 1994-1998 & 1025 & 335 & 32.7 & -10.2 \\
\hline & 1999-2003 & 1144 & 410 & 35.8 & 15.0 \\
\hline & 2004-2008 & 1573 & 552 & 35.1 & 28.4 \\
\hline & $1977-2008$ & & & & 9.9 \\
\hline \multirow{7}{*}{ Temperate deciduous forests ${ }^{\mathrm{d})}$} & 1977-1981 & 2425 & 870 & 35.9 & - \\
\hline & 1984-1988 & 3793 & 1400 & 36.9 & 75.7 \\
\hline & 1989-1993 & 4129 & 1539 & 37.3 & 27.8 \\
\hline & 1994-1998 & 3694 & 1566 & 42.4 & 5.4 \\
\hline & 1999-2003 & 3824 & 1626 & 42.5 & 11.8 \\
\hline & 2004-2008 & 3820 & 1577 & 41.3 & -9.7 \\
\hline & 1977-2008 & & & & 26.2 \\
\hline \multirow{7}{*}{ Temperate/subtropical mixed forests ${ }^{\mathrm{e})}$} & $1977-1981$ & 3697 & 816 & 22.1 & - \\
\hline & 1984-1988 & 3459 & 703 & 20.3 & -16.2 \\
\hline & 1989-1993 & 4158 & 901 & 21.7 & 39.7 \\
\hline & 1994-1998 & 4239 & 1016 & 24.0 & 23.1 \\
\hline & 1999-2003 & 4528 & 1256 & 27.7 & 47.9 \\
\hline & 2004-2008 & 3855 & 1156 & 30.0 & -20.0 \\
\hline & 1977-2008 & & & & 12.6 \\
\hline \multirow{7}{*}{ Evergreen broadleaf forests ${ }^{\mathrm{f}}$ ) } & $1977-1981$ & 3217 & 1284 & 39.9 & - \\
\hline & 1984-1988 & 2666 & 982 & 36.8 & -43.2 \\
\hline & 1989-1993 & 2221 & 893 & 40.2 & -17.8 \\
\hline & 1994-1998 & 2151 & 834 & 38.8 & -11.9 \\
\hline & 1999-2003 & 2956 & 1308 & 44.3 & 94.9 \\
\hline & 2004-2008 & 4506 & 1901 & 42.2 & 118.6 \\
\hline & 1977-2008 & & & & 22.8 \\
\hline
\end{tabular}

a) The classification is based on Fang (2000). b) Dominant species: Picea, Abies, Larix. c) Dominant species: Pinus koraiensis, P. sylyestris var. mongolica, P. tabulaefomis, P. armandii, P. densiflora, P. thunbergii, P. densata, P. griffithii, and other pine forests, mixed coniferous forests, Cupressus, Tsuga, and other coniferous forests. d) Dominant species: Populus, Betula, Tilia, Quercus, Fraxinus mandschurica, Juglans mandshurica, Phellodendron amurense, Paulownia. e) Dominant species: Pinus massoniana, P. yunnanensis, P. kesiya var. langbianensis, Cunninghamia lanceolata, Cryptomeria, Sassafras, Keteleeria, mixed coniferous and deciduous forests, Metasequoia, nonmerchantable woods. f) Dominant species: Cinnamomum, Phoebe, Eucalyptus, Casuarina, tropical forests, mixed broad-leaved forests, other hard broad-leaved forests, other soft broad-leaved forests, and coppice forests.

were grouped into three age classes: young-aged, mid-aged, and old-aged forests (including premature forests, mature forests, and over-mature forests). The temporal change of areas, $\mathrm{C}$ stocks, and $\mathrm{C}$ densities among three age classes in China's forest stands are shown in Figure 4. About $54.4 \%$ $-55.0 \%$ of total biomass $\mathrm{C}$ stock of forest stands occurred in the old-aged forests, which had sequestrated $\mathrm{C}$ of $930 \mathrm{Tg}$, at an average rate of $34.5 \mathrm{Tg} \mathrm{C} \mathrm{a}^{-1}$. The mid-aged forests had sequestrated $\mathrm{C}$ of $391 \mathrm{Tg}(22.9 \%-32.6 \%$ of total $\mathrm{C}$ stock of forest stands), at an average rate of $14.5 \mathrm{Tg} \mathrm{C} \mathrm{a}^{-1}$. The smallest biomass $\mathrm{C}$ sink (388 or $14.4 \mathrm{Tg} \mathrm{C} \mathrm{a}^{-1}$ ) was in the young-aged forests $(12.8 \%-17.0 \%$ of total $\mathrm{C}$ stock).
These C sinks were mainly attributed to the increase in forest area in each age class: from 1977 through 2008, forest area has increased by $12.73 \times 10^{6}$ ha in the old-aged forests, $10.76 \times 10^{6}$ ha in the young-aged forests, and $8.60 \times 10^{6}$ ha in the mid-aged forests, which accounted for $39.7 \%, 33.5 \%$, and $26.8 \%$ of total area increment in China's forest stands. In addition, forest regrowth in each age class over the past three decades was also responsible for these $\mathrm{C}$ sinks: compared to the initial $\mathrm{C}$ density in the early 1980s (14.4, 35.4 and 67.4 $\mathrm{Mg} \mathrm{C} \mathrm{ha}^{-1}$ in the young-, mid- and old-aged forests, respectively, for 1977-1981), the area-weighted mean biomass $\mathrm{C}$ density has increased $31.3 \%$ in the young-aged 

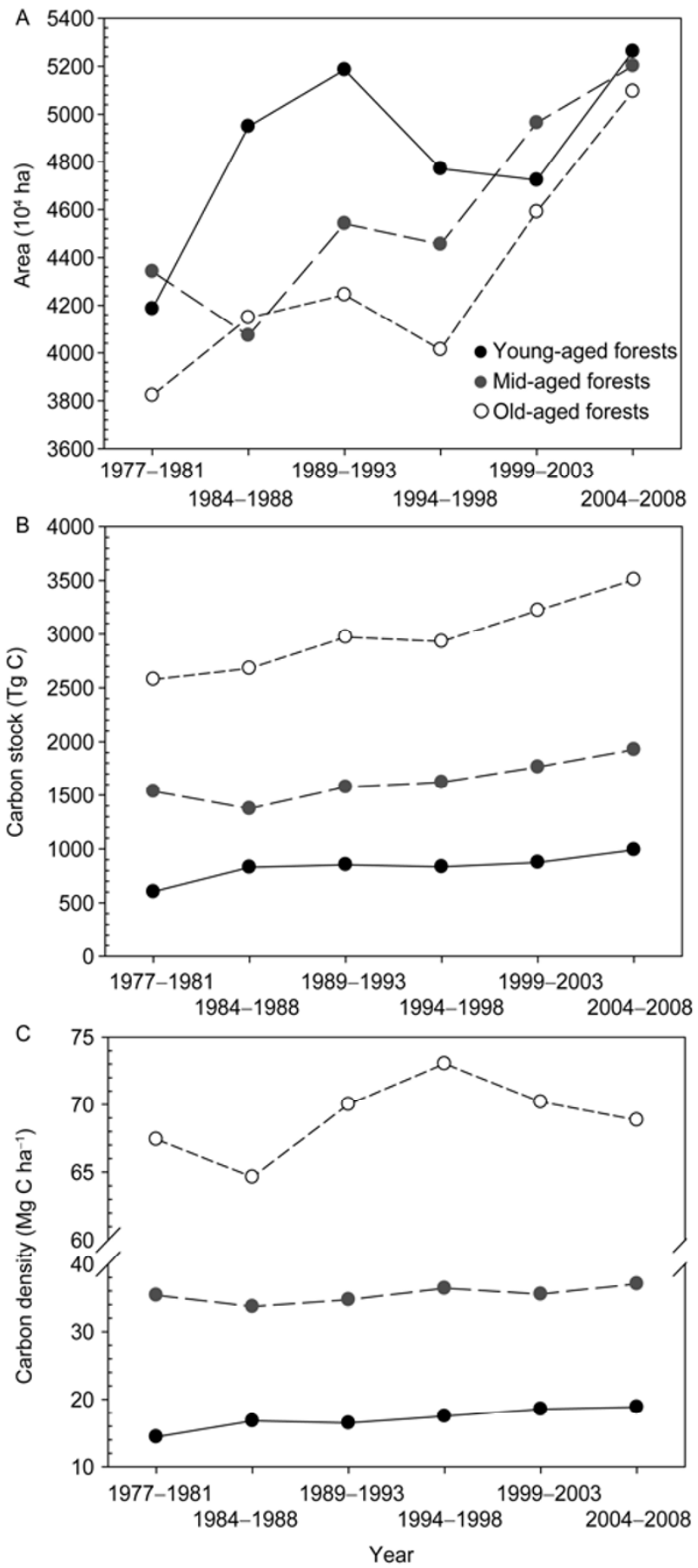

Figure 4 Area (A), C stock (B), and C density (C) of China's forest stands among different age classes during 1977-2008.

forests, $4.8 \%$ in the mid-aged forests, and $2.1 \%$ in the old-aged forests by the late 2000s (2004-2008), respectively. Note that the mean biomass $\mathrm{C}$ density of the old-aged forests $\left(68.8 \mathrm{Mg} \mathrm{Cha}^{-1}\right.$ ) was 1.9 and 3.7 times that of the mid-aged (37.1 $\mathrm{Mg} \mathrm{C} \mathrm{ha}{ }^{-1}$ ) and young-aged forests (18.9 $\mathrm{Mg} \mathrm{C} \mathrm{ha}{ }^{-1}$ ) in 2004-2008, indicating that the young- and mid-aged forests could sequestrate more $\mathrm{C}$ in the future if we keep these forests growing.

\section{Discussion}

\subsection{Estimates of biomass $\mathrm{C}$ sink in China's forest}

In this study, we estimated that the annual biomass $\mathrm{C}$ sink in China's forests averaged 70.2 $\mathrm{Tg} \mathrm{C}$ during the period of 1977-2008, of which 63.3 Tg C was in the forest stands, 4.0 $\mathrm{Tg} \mathrm{C}$ in the economic forests, and $2.9 \mathrm{Tg} \mathrm{C}$ in the bamboo forests. Using the linear conversion equations for estimating provincial biomass C stocks before 1994, Fang et al. [18] reported that the mean biomass $\mathrm{C}$ sink of China's forest stands was 75.2 $\mathrm{Tg} \mathrm{C} \mathrm{a}^{-1}$ during the period of 1977-2003, which was greater than our estimate $(63.3 \mathrm{Tg} \mathrm{C})$. This may be because the linear conversion equations could underestimate biomass C stocks of forest stands before 1994 when converting provincial biomass $\mathrm{C}$ stocks from the old criterion ( $>30 \%$ of canopy coverage) to the new criterion $(\geqslant 20 \%$ canopy coverage). Using the new forest criterion and updated China's forest inventory data, Pan et al. [11] estimated that the mean biomass $\mathrm{C}$ sink of China's forests was 60 and $115 \mathrm{Tg} \mathrm{C} \mathrm{a}{ }^{-1}$ for the periods of 1990-1999 and 2000-2007, both were close to our estimates: in our study, the value was $60 \mathrm{Tg} \mathrm{C} \mathrm{a}^{-1}$ during 1989-1998 (the average of the periods 1989-1993 and 1994-1998; Table 1) and 109 Tg C a ${ }^{-1}$ during 1999-2008 (the average of the periods 1999-2003 and 2004-2008; Table 1).

On the other hand, using the mean shoot numbers of bamboo, Pan et al. [26] estimated that the bamboo biomass C stock increased from 65 to 80 Tg C during 1977-1993, with a net $\mathrm{C}$ accumulation of $15 \mathrm{Tg} \mathrm{C}$. Compared with this, we estimated that the $\mathrm{C}$ stock of the bamboo forests increased from 121 to $138 \mathrm{Tg}$ C during 1977-1993, with a net accumulation of $17 \mathrm{Tg} \mathrm{C}$, using the mean biomass densities of bamboos. This shows that our estimates of the $\mathrm{C}$ stocks were greater than those by Pan et al. [26], but the strength of the $\mathrm{C}$ sink was quite close to each other.

In order to compare the strength of the $\mathrm{C}$ sink with other countries and regions, we estimated that the average value of biomass $\mathrm{C}$ sink in China's forests was $0.44 \mathrm{Mg} \mathrm{C} \mathrm{ha}^{-1} \mathrm{a}^{-1}$ by using an average forest area of $159.0 \times 10^{6}$ ha during 1977-2008. Similarly, we estimated the averaged value of the $\mathrm{C}$ sinks in China's forests between two sequential inventory periods: $0.21 \mathrm{Mg} \mathrm{C} \mathrm{ha}^{-1} \mathrm{a}^{-1}$ (1977-1988), $0.72 \mathrm{Mg}$ $\mathrm{C} \mathrm{ha}^{-1} \mathrm{a}^{-1}$ (1984-1993), 0.06 Mg C ha $\mathrm{a}^{-1}$ (1989-1998), $0.63 \mathrm{Mg} \mathrm{C} \mathrm{ha} \mathrm{a}^{-1}$ (1994-2003), and 0.66 Mg C ha $\mathrm{Ma}^{-1}$ (1999-2008). As shown in Table 4, the overall strength of China's forest biomass $\mathrm{C}$ sink during the past three decades was smaller than that in the Northern Hemisphere countries, but since the middle 1990s, it had increased greatly (0.63-0.66 Mg C ha $\mathrm{Mg}^{-1}$ ), and was somewhat comparable with that of the United States and Russia, although it was still lower than that of Europe and Japan. 
Table 4 Estimated biomass C sink strength $\left(\mathrm{Mg} \mathrm{C} \mathrm{ha}^{-1} \mathrm{a}^{-1}\right)$ by country or region in the Northern Hemisphere for the periods of 1990-1999 and 2000-2007 (modified from Pan et al. [11])

\begin{tabular}{ccr}
\hline Country or region & \multicolumn{2}{c}{${\text { C sink capacity }\left(\mathrm{Mg} \mathrm{C}^{-1} \mathrm{a}^{-1}\right)}^{2000-2007}$} \\
\cline { 2 - 3 } China & $1990-1999$ & 0.77 \\
Canada & 0.43 & 0.03 \\
United States $^{\mathrm{a})}$ & 0.47 & 0.58 \\
Europe & 1.09 & 1.31 \\
Japan & 0.99 \\
Russia & 0.33 & 0.61 \\
\hline
\end{tabular}

a) The United States only include conterminous U.S. and Southeast Alaska.

\subsection{Contribution of planted and natural forests to total biomass $\mathrm{C}$ sink}

China holds the largest plantation area in the world, and therefore planted forests could play an important role in sequestrating atmospheric $\mathrm{CO}_{2}[3,27]$. In our study, among a total of $1710 \mathrm{Tg} \mathrm{C}$ sequestration in China's forest stands during the year of 1977-2008, planted forests have sequestrated $\mathrm{C}$ of $818 \mathrm{Tg}$, contributing almost half of total biomass $\mathrm{C}$ sink in China's forest stands (Table 2). Because the area and biomass density of planted forests have persistently increased since the early 1980s, forest expansion and regrowth are mainly responsible for this C sink. Similarly, Fang et al. [3] reported that planted forests had sequestrated 0.45 Pg C during 1973-1998 because of forest expansion (from $17.4 \times 10^{6}$ to $23.1 \times 10^{6}$ ha) and regrowth (from 15.3 to 31.1 $\mathrm{Mg} \mathrm{C} \mathrm{ha}^{-1}$ ).

Although the area of natural forests was about four times that of planted forests, natural forests have only sequestrated the nearly same amount of C (892 Tg C) as did planted forests over the past 30 years. However, the mechanism responsible for the $\mathrm{C}$ sink in natural forests is different with that for the planted forests. During 1977-1998, although the area of natural forests decreased from $107.55 \times 10^{6}$ ha in $1977-1981$ to $103.26 \times 10^{6}$ ha in $1994-1998$, natural forests sequestrated a net of $278 \mathrm{Tg} \mathrm{C}$. That is to say, forest regrowth (from $41.5 \mathrm{Mg} \mathrm{C} \mathrm{ha}^{-1}$ in 1977-1981 to $46.0 \mathrm{Mg} \mathrm{C}$ $\mathrm{ha}^{-1}$ in 1994-1998) is the main causes of the C sequestration. With the implementation of the Natural Forest Conservation Program since 1998 across the country, the area of natural forests had expanded since the late 1990s (19941998), and therefore forest expansion (from $103.26 \times 10^{6}$ ha in $1994-1998$ to $115.59 \times 10^{6}$ ha in $2004-2008$ ) was likely playing a major role in the increased $\mathrm{C}$ stocks in natural forests because of consistent biomass $\mathrm{C}$ density in natural forests during this period (46.0 $\mathrm{Mg} \mathrm{C} \mathrm{ha}^{-1}$ in 1994-1998 and 46.4 $\mathrm{Mg} \mathrm{C} \mathrm{ha}^{-1}$ in 2004-2008).

\subsection{Implication of forest $\mathrm{C}$ sink in China}

Using the data of energy consumption and cement production recorded in "China Statistical Yearbook" and the similar methods mentioned in Fang et al. [41], we estimated
China's fossil-fuel $\mathrm{CO}_{2}$ emissions as $27.7 \mathrm{Pg} \mathrm{C}$ during 1977-2008, at an average emission rate of $895 \mathrm{Tg} \mathrm{C} \mathrm{a}^{-1}$. Therefore, the biomass $\mathrm{C}$ sink of $70.2 \mathrm{Tg} \mathrm{C} \mathrm{a}^{-1}$ in China's forests offsets $7.8 \%$ of the contemporary fossil $\mathrm{CO}_{2}$ emissions in China, of which forest stands offsets about $7.1 \%$. Pan et al. [11] reported that China's forest biomass $\mathrm{C}$ sink accounted for $44.4 \%-63.2 \%$ of total C sink in the country's whole forest sector (dead wood, harvested wood products, living biomass, litter, and soil) for the period of 1990-2007, which suggested the whole China's forests could sequester 111.1-158.1 $\mathrm{Tg} \mathrm{C} \mathrm{a}^{-1}$, or equal $12.4 \%-17.1 \%$ of the contemporary fossil $\mathrm{CO}_{2}$ emissions from 1977 through 2008, if the biomass $\mathrm{C}$ sink rate of $70.2 \mathrm{Tg} \mathrm{C} \mathrm{a}^{-1}$ in China's forests was applied.

\subsection{China's forest biomass $\mathrm{C}$ in the future}

With the enhanced afforestation and reforestation practices, natural forest protection, and effective forest management, China's forest biomass $\mathrm{C}$ stocks will continuously increase in the next decades. Here we figure out the $\mathrm{C}$ sink potential for China's forest stands in the future, simply considering two factors, increase of forest area and forest regrowth.

\subsubsection{Increase of forest area}

The current forest coverage is $20.4 \%$ in China, of which forest stands is $16.2 \%\left(155.6 \times 10^{6} \mathrm{ha}\right)$, with the mean biomass density of $41.3 \mathrm{Mg} \mathrm{C} \mathrm{ha}^{-1}$. According to the middle and long-term state forestry development plan, the forest coverage would be $24 \%$ in 2030 [42], which means that the area of China's forest stands (assuming the constant proportion of forest stands to total forests) will increase to $183.1 \times 10^{6}$ ha in the next two decades. Assuming an invariable mean biomass $\mathrm{C}$ density of forest stands (41.3 $\mathrm{Mg} \mathrm{C}$ $\mathrm{ha}^{-1}$ ), the biomass $\mathrm{C}$ stock of forest stands will increase by $1135 \mathrm{Tg} \mathrm{C}$, from $6427 \mathrm{Tg} \mathrm{C}$ at present to $7562 \mathrm{Tg} \mathrm{C}$ in 2030 .

\subsubsection{Forest regrowth}

Within forest stands, planted forests occupy $25.7 \%$ of total forest stand area $\left(40.0 \times 10^{6}\right.$ ha) with a low mean biomass density of $26.7 \mathrm{Mg} \mathrm{C} \mathrm{ha}^{-1}$ in 2004-2008. However, the 
mean biomass density of natural forests is up to $46.4 \mathrm{Mg} \mathrm{C}$ $\mathrm{ha}^{-1}$ at the same period. When these planted forests grow up to the same biomass $\mathrm{C}$ density as natural forests did, these forests could sequestrate about $788 \mathrm{Tg} \mathrm{C}$. In addition, young- and mid-aged forests occupy $67.2 \%$ of total forest stand area $\left(52.6 \times 10^{6}\right.$ ha for the former and $52.0 \times 10^{6}$ ha for the latter) with the mean biomass $\mathrm{C}$ density of 18.9 and 37.1 $\mathrm{Mg} \mathrm{C} \mathrm{ha}{ }^{-1}$, respectively. If these young- and mid-aged forests could grow up to be as old as the old-aged forests (currently its mean biomass $\mathrm{C}$ density is $68.8 \mathrm{Mg} \mathrm{C} \mathrm{ha}^{-1}$ ), these forests will sequester $\mathrm{C}$ of $4273 \mathrm{Tg}$ in the future. In other words, even without an increase in forest area, China's forests will still sequester considerable amounts of $\mathrm{CO}_{2}$ from the atmosphere because of their regrowth.

\subsection{Error analyses}

Error analysis of the estimates of national forest biomass $\mathrm{C}$ stocks based on inventory data was rarely reported, mainly because many sources of error make it complex. For the forest stands, the most important errors may come from forest inventory data and the estimation of regional biomass stocks by applying for BEFs. For example, Phillips et al. [43] analyzed the error in estimates of forest timber volumes and their changes in five southeastern states in the United States. In their study, the error sources included sampling error, measurement error and regression error, of which sampling error was mainly responsible for the total error in forest timber volumes and their changes, accounting for $90 \%-99 \%$ of total variance. However, the estimation of forest timber volumes is only the first step to estimate forest biomass stocks, and the regression error in subsequent steps that convert timber volume to biomass need to be further investigated [43]. Forest inventory data used in our study specified the precision requirement in sampling design: the forest area and volume precision were required to be $>90 \%$ in almost each province ( $>85 \%$ in Beijing, Shanghai and Tianjin) [44]. In addition, the $R$ square values of BEF equations used to convert timber volume to biomass were above 0.8 for most dominant tree species (Table S1). Therefore, the data and method used in this study have relatively high precision. For example, Fang et al. [22] reported that the estimation error of biomass stocks in the national level should be less than $3 \%$.

For the economic and bamboo forests, the major error may be generated from the use of the mean biomass density. In general, the method could result in some overestimation of biomass stocks of economic and bamboo forests [34] because collected data were usually from forest stands with better growing conditions. Additional, using the constant $\mathrm{C}$ conversion factor of 0.5 might also yield some errors.

This study does not include other forest components recorded in China's forest inventory data, including farmland protection forest, and four-side greening trees (trees out forests). In the past decades, the farmland protection forest and four-side greening trees have significantly increased in China, perhaps resulting in an increase of their C stocks, which need to be assessed in the future [45].

We thank Chen AnPing, Liu GuoHua and others for constructing an early version of the field biomass measurement dataset for Table S1 in Supporting Information. This work was supported by the National Basic Research Program of China on Global Change (2010CB950600), the National Natural Science Foundation of China (31021001, 30721140306), and 'Strategic Priority Research Program-Climate Change: Carbon Budget and Related Issues' of the Chinese Academy of Sciences (XDA05050503).

1 Kauppi P E, Mielikainen K, Kusela K. Biomass and carbon budget of European forests, 1971 to 1990. Science, 1992, 256: 70-74

2 Dixon R K, Brown S, Houghton R A, et al. Carbon pools and flux of global forest ecosystems. Science, 1994, 263: 185-190

3 Fang J Y, Chen A P, Peng C H, et al. Changes in forest biomass carbon storage in China between 1949 and 1998. Science, 2001, 292: 2320-2322

4 Fang J Y, Brown S, Tang Y H, et al. Overestimated biomass carbon pools of the northern mid- and high latitude forests. Clim Change, 2006, 74: 355-368

5 Pacala S W, Hurtt G C, Baker D, et al. Consistent land- and atmosphere-based US carbon sink estimates. Science, 2001, 292: 2316-2320

6 Goodale C L, Apps M J, Birdsey R A, et al. Forest carbon sinks in the Northern Hemisphere. Ecol Appl, 2002, 12: 891-899

7 Janssens I A, Freibauer A, Ciais P, et al. Europe's terrestrial biosphere absorbs 7 to $12 \%$ of European anthropogenic $\mathrm{CO}_{2}$ emissions. Science, 2003, 300: 1538-1542

8 Bonan G B. Forests and climate change: forcings, feedbacks, and the climate benefits of forests. Science, 2008, 320: 1444-1449

9 Yang T H, Song K, Da L J, et al. The biomass and aboveground net primary productivity of Schima superba-Castanopsis carlesii forests in east China. Sci China Life Sci, 2010, 53: 811-821

10 Zhang Q Z, Wang C K. Carbon density and distribution of six Chinese temperate forests. Sci China Life Sci, 2010, 53: 831-840

11 Pan Y, Birdsey R A, Fang J Y, et al. A large and persistent carbon sink in the world's forests. Science, 2011, 333: 988-993

12 He J S. Carbon cycling of Chinese forests: from carbon storage, dynamics to models. Sci China Life Sci, 2012, 55: 188-190

13 Brown S, Sathaye J, Cannell M, et al. Mitigation of carbon emission to the atmosphere by forest management. Commonw Forest Rev, 1996, 75: 80-91

14 Brown S L, Schroeder P, Kern J S. Spatial distribution of biomass in forests of the eastern USA. Forest Ecol Manage, 1999, 123: 81-90

15 Brown S L, Schroeder P E. Spatial patterns of aboveground production and mortality of woody biomass for eastern U.S. forests. Ecol Appl, 1999, 9: 968-980

$16 \mathrm{Hu} \mathrm{H} \mathrm{F,} \mathrm{Wang} \mathrm{G} \mathrm{G.} \mathrm{Changes} \mathrm{in} \mathrm{forest} \mathrm{biomass} \mathrm{carbon} \mathrm{storage} \mathrm{in} \mathrm{the}$ South Carolina Piedmont between 1936 and 2005. Forest Ecol Manage, 2008, 255: 1400-1408

17 Fang J Y, Oikawa T, Kato T, et al. Biomass carbon accumulation by Japan's forests from 1947 to 1995. Global Biogeochem Cycles, 2005, 19, GB2004, doi: 10.1029/2004GB002253

18 Fang J Y, Guo Z D, Piao S L, et al. Terrestrial vegetation carbon sinks in China, 1981-2000. Sci China Ser D-Earth Sci, 2007, 50: 1341-1350

19 Marland G, Andres R J, Boden T A. Global, regional, and national $\mathrm{CO}_{2}$ emissions. In: Boden T A, Kaiser D P, Sepanski R J, et al., eds. Trends '93: a compendium of data on global change. ORNL/CDIAC65. Oak Ridge: Carbon Dioxide Information Analysis Center, Oak Ridge National Laboratory, 1994. 505-584

20 Ministry of Forestry of China. Forest Resource Report of China-the 7th National Forest Resources Inventory (in Chinese). Beijing: China Forestry Publishing House, 2009. 2 
21 Fang J Y, Tang Y H, Son Y. Why are East Asian ecosystems important for carbon cycle research. Sci China Life Sci, 2010, 53: 561-565

22 Fang J Y, Liu G H, Xu S L. Biomass and net production of forest vegetation in China (in Chinese). Acta Ecol Sin, 1996, 16: 497-508

23 Fang J Y, Wang G G, Liu G H, et al. Forest biomass of China: an estimation based on the biomass-volume relationship. Ecol Appl, 1998, 8: 1084-1091

24 Liu G H, Fu B J, Fang J Y. Carbon dynamics of Chinese forests and its contribution to global carbon balance (in Chinese). Acta Ecol Sin, 2000, 20: 733-740

25 Wang X K, Feng Z W, Ouyang Z Y. The impact of human disturbance on vegetative carbon storage in forest ecosystems in China. Forest Ecol Manage, 2001, 148: 117-123

26 Pan Y D, Luo T X, Birdsey R, et al. New estimates of carbon storage and sequestration in China's forests: effects of age-class and method on inventory-based carbon estimation. Clim Change, 2004, 67: 211-236

27 Piao S L, Fang J Y, Zhu B, et al. Forest biomass carbon stocks in China over the past 2 decades: estimation based on integrated inventory and satellite data. J Geophys Res, 2005, 110, G01006, doi:10.1029/2005JG000014

28 Piao S L, Fang J Y, Ciais P, et al. The carbon balance of terrestrial ecosystems in China. Nature, 2009, 458: 1009-1013

29 Piao S L, Ito A, Li S G, et al. The carbon budget of terrestrial ecosystems in East Asia over the last two decades. Biogeosciences, 2012, 9: 3571-3586

30 Xu X L, Cao M K, Li K R. Temporal-spatial dynamics of carbon storage of forest vegetation in China (in Chinese). Progr Geogr, 2007, 26: $1-10$

31 Wu Q B, Wang X K, Duan X N, et al. Carbon sequestration and its potential by forest ecosystems in China (in Chinese). Acta Ecol Sin, 2008, 28: 517-524

32 Liu S N, Zhou T, Wei L Y, et al. The spatial distribution of forest carbon sinks and sources in China. Chin Sci Bull, 2012, 57: 1699-1707

33 Fang J Y, Wang Z M. Forest biomass estimation at regional and global levels, with special reference to China's forest biomass. Ecol Res, 2001, 16: 587-592

34 Guo Z D, Fang J Y, Pan Y D, et al. Inventory-based estimates of forest biomass carbon stocks in China: a comparison of three methods. Forest Ecol Manage, 2010, 259: 1225-1231

35 Brown S, Lugo A E. Aboveground biomass estimates for tropical moist forests of Brazilian Amazon. Interciencia, 1992, 17: 8-18

36 Schroeder P, Brown S, Mo J, et al. Biomass estimation for temperate broadleaf forests of the United States using inventory data. Forest Sci, 1997, 43: 424-434

37 Fang J Y, Chen A P, Zhao S Q, et al. Estimating biomass carbon of China's forests: supplementary notes on report published in Science (2001, 291: 2320-2322) by Fang et al. 2001 (in Chinese). Acta Phytoecol Sin, 2002, 26: 243-249

38 Fang J Y, Chen A P. Dynamic forest biomass carbon pools in China and their significance (in Chinese). Acta Botan Sin, 2001, 43: 967-973

39 Fang J Y, Shen Z H, Tang Z Y, et al. Forest community survey and the structural characteristics of forests in China. Ecography, 2012, 35: 1059-1071

40 Fang J Y. Forest productivity in China and its responses to global climate change. Acta Phytoecol Sin, 2000, 24: 513-517

41 Fang J Y, Liu G H, Xu S L. Carbon cycling in terrestrial ecosystems in China. In: Wang G C, Wen Y P, eds. Emissions and Their Relevant Processes of Greenhouse Gases in China (in Chinese). Beijing: Chinese Environmental Science Publishers, 1996. 81-149

42 Xu B, Guo Z D, Piao S L, et al. Biomass carbon stocks in China's forests between 2000 and 2050: a prediction based on forest biomass-age relationships. Sci China Life Sci, 2010, 53: 776-783

43 Phillips D L, Brown S, Schroeder P E, et al. Towards error analysis of large-scale forest carbon budgets. Global Ecol Biogeogr, 2000, 9: 305-313

44 Xiao X W, ed. Forest Resource Inventory of China (in Chinese). Beijing: China Forestry Publishing House, 2005

45 Guo Z D. Biomass carbon stocks and ecosystem carbon budget in China's forests (in Chinese). Dissertation for Doctoral Degree. Beijing: Peking University, 2011

Open Access This article is distributed under the terms of the Creative Commons Attribution License which permits any use, distribution, and reproduction in any medium, provided the original author(s) and source are credited.

\section{Supporting Information}

Table S1 Parameters of the continuous biomass expansion factor (BEF) method for China's major forest types (modified from Guo et al. [34])

The supporting information is available online at life.scichina.com and www.springerlink.com. The supporting materials are published as submitted, without typesetting or editing. The responsibility for scientific accuracy and content remains entirely with the authors. 